\title{
KONSELING PERNIKAHAN BERBASIS BUDAYA SINOMAN JAWA
}

\author{
Sesya Dias Mumpuni, Dita Efani, Winahyu Destyarti, Indra Tirto Aji \\ Universitas Pancasakti Tegal \\ Email: dias.mumpuni@upstegal.ac.id
}

\begin{abstract}
Abstrak
Semakin semaraknya tren yang banyak menjadikan remaja atau dewasa dengan usia siap menikah menjadi rentan dan kehilangan diri untuk lebih mengetahui wawasan berumah tangga, dukungan lingkungan yang memudar membuat individu tersebut menjadi tidak menyadari adanya budaya yang nilainya dekat dengan hal - hal berkaitan dengan pernikahan. Melalui penelitian ini, bertujuan untuk mengembalikan budaya yang sejatinya sudah ada di lingkungan untuk dapat di aplikasikan bagi mereka yang melangsungkan ikatan yang lebih sakral sebagai solusi dari stigmasisasi lajang dan kerentanan terhadap kekerasan yang diterima oleh orang - orang dengan risiko kehamilan tidak di inginkan serta membantu untuk pihak terkait mempromosikan untuk memiliki keluarga terencana. Metode yang digunakan dalam penelitian ini adalah kuantitatif deskriptif dimana data dikumpulkan menggunakan google form terdiri dari 50 responden dengan dominasi jenis kelamin perempuan. Responden berasal dari domisili beberapa wilayah di pulau Jawa dengan perolehan tiga tertinggi dari Pemalang sebesar 17.1\%, Kabupaten Tegal sebesar 22,9\% dan Kabupaten Brebes sebesar 24,3\% serta total kesiapan pernikahan masih lama dari 50 responden memberikan hasil $55,7 \%$ hal tersebut dapat dijadikan acuan untuk memberikan wawasan tentang pentingnya informasi menjelang pernikahan yang perlu dipersiapkan. Tingkat kevalidan data yang dikumpulkan merujuk pada indikator variable kondisi hubungan, cinta remaja, persiapan pernikahan, pager ayu, ladhen wedhang serta rewang pada 50 responden dari beberapa daerah khususnya wilayah Jawa, usia 21 tahun keinginan menikah tertinggi memiliki tingkat kevalidan yang kuat sebanyak 41 item dan satu item tidak valid pada nomor tiga dengan bunyi item berikut "Kami dikenalkan oleh rekan kerja" serta reliabilitas menunjukan koefisien reliabilitas sebesar $\alpha=0.943$. Item tertinggi dengan kesesuaian indikator utama dari Sinoman Jawa yakni pada pernyataan pernikahan sebagai gerbang utama dari perjalanan yang panjang sehingga harus dibarengi dengan limpahan kesabaran untuk mampu menerima apapun kondisi pasangan yang memperoleh layanan terbaik juga terhadap orang tua hal tersebut didukung dengan komunikasi atau tukar pendapat bersama pasangan sebagai kunci terhindari dari permasalahan.
\end{abstract}

Kata Kunci : Budaya Jawa, Bimbingan, Konseling, Kuantitatif, Pernikahan 



\section{PENDAhuluan}

Indonesia menyimpan keberagaman budaya dalam masyarakatnya, salah satu bukti keberagamannya datang dari pulau dengan jumlah penduduk yang banyak. Wilayah Jawa, terkenal dengan unggah - ungguh dalam tatanan kehidupannya. Seluruh aspek kegiatan tidak luput dari nilai dan makna, salah satunya adalah pernikahan. Pernikahan dipandang sebagai momen sakral dan tidak bias sembarang dilakukan, ada aturan - aturan yang mengatur dalam pelaksanaannya pun sarat maknanya. Sinoman menjadi salah satu budaya yang muncul dari kebiasaan masyarakat Jawa bergotong royong dalam menyelenggarakan kegiatan pernikahan seseorang yang juga mengandung sarat dan makna yang prinsipnya bisa di implementasikan sebagai pendeketakan pada proses pemberian bantuan dari seorang ahli disebut dengan konselor kepada orang yang membutuhkan bantuan disebut dengan konseli (Prayitno \& Amti, 2004).

Manusia sejatinya merupakan mahluk yang saling membutuhkan satu dengan yang lain, seiring perkembangan zaman dengan kemudahan akses yang ditawarkan oleh teknologi semakin memudahkan manusia dalam melakukan kegiatan interaksi. Interaksi yang kurang dalam dunia nyata bukan berarti menjadikan individu merasa butuh ditemani dalam waktu dekat karena hal tersebut bisa mereka peroleh hanya dari genggaman. Di beberapa Negara, melakukan kegiatan sendiri muncul sebagai kebiasaan salah satunya termuat dalam artikel Solo dining in Chinese restaurants: A mixed-method study in Macao bahwa "Findings show that freedom of choice and satisfying hunger are the main motivations for solo dining, and some solo-friendly attributes, foodrelated attributes, and restaurant characteristics are considered as important elements. Solo dining is perceived positively, partly because its perceptions and experiences are shaped by the diners' socio-cultural backgrounds and unique regional characteristics, in which solo dining is considered relatively common in Macao as opposed to extant literature that has suggested an essentialised assumption about Chinese group-oriented dining preference. Sociocultural insights and managerial implications are provided in catering to the growing solo diner market”. (Choi, Yang, \& Tabari, 2020)

Makan sendirian dipandang positif, sebagian karena persepsi dan pengalamannya dibentuk oleh latar belakang budaya sosial pengunjung dan karakteristik daerah yang unik, di mana makan malam tunggal dianggap relatif umum di Makau. Berlainan dengan Negara tersebut, individu yang makan malam sendirian di ruang terbuka di indikasikan sebagai seseorang yang merasa kesepian atau tengah melajang, status melajang dengan kategori usia tertentu dapat menimbulkan perspektif tang dapat memberikan dampak terhadap individu sebuah jurnal Modernization and singlehood in Indonesia: Psychological and social impacts "Singles in Indonesia as a Target of Despisement While modernization influences individual lifestyle and personal values particularly among younger adults, the majority of Indonesian society is attached to conservative and pseudoreligious based beliefs. In this context, marriage is regarded as a social achievement and as being mandatory for every adult of marriageable age. As a result, remaining single is socially 
defined as being a failure and singles past marriageable age are negatively stigmatized. Women may be subject to greater stigmatization. A popular term for single women in Indonesia is 'perawan tua' (meaning: spinster), whereas there is no known term for single men. Single women approaching or passing the acceptable marriageable age are blamed for being too choosy and selfishly selective. Nonetheless, argues that being selective for single women can be legitimate even if it is contradictory to social definition. Being selective provides women with 'social power' as it puts them in the position of being the choice maker. No published study has been identified that examines the psychological impact of social stigma on singles. However, unpublished pilot data suggests that only 14 percent of singles reported low social pressure, while more than 25 percent of singles reported high and extremely high social pressure." (Himawan, Bambling, \& Edirippulige, 2017). Dengan demikian, pernikahan dianggap sebagai pencapaian sosial dan wajib bagi setiap orang dewasa dalam usia menikah. Akibatnya, tetap melajang secara sosial dianggap sebagai kegagalan dan para lajang yang telah melewati usia menikah mendapat stigma negative dengan memberikan istilah tertentu terhadap pria dan wanita yang melajang. Sebuah pendapat menyatakan bahwa bersikap selektif untuk wanita lajang bisa menjadi sah meskipun bertentangan dengan sosial. Termuat pada artikel Vulnerability mapping: A conceptual framework towards a context-based approach to women's empowerment bahwa "The process of empowerment itself (that is, a change in women's vulnerability status over time) takes place in the four domains of empowerment: access, awareness, opportunities, and mental space." (Gressel, et al., 2020) di mana proses pemberdayaan itu sendiri merupakan perubahan pada perempuan status kerentanan dari waktu ke waktu terjadi di empat domain pemberdayaan: akses, kesadaran, peluang, dan ruang mental. Menjadi selektif memberi wanita 'kekuatan sosial' karena menempatkan mereka pada posisi sebagai pembuat pilihan. Kekuatan sosial ini didukung dengan keberadaan kesetaraan antara laki - laki dan perempuan untuk melindungi perempuan dari kekerasan, pada artikel Impacts of a Cash Plus Intervention on Gender Attitudes Among Tanzanian Adolescents mengungkapkan hasil analisis kesetaraan bahwa "Our analysis indicates that the life skills training has had positive impacts on equitable gender norms attitudes only among males. The largest and most precisely estimated impact soon after the intervention was on the domestic chores and daily life domain, with weaker evidence of impact on the violence, and sexual relationships subscales. At the 12-month follow-up, there was an impact on the violence and domestic chores subscales only. The fact that we found fewer and less precisely estimated impacts on the domains related to sexual relationships, and reproductive health is perhaps explained by the fact that fewer adolescents would have had a direct experience of these issues in a sample where fewer than one in five $(17 \%)$ of 14- to 19-year-olds reported having had a sexual intercourse at baseline." (Chzhen, et al., 2020). Pelatihan kecakapan hidup berdampak positif terhadap kesetaraan aturan hanya di kalangan laki-laki. Dampak terbesar 
dan paling tepat diperkirakan segera setelah intervensi terjadi pada pekerjaan rumah tangga dan domain kehidupan sehari-hari, dengan bukti yang lebih lemah tentang dampak pada kekerasan, dan subskala hubungan seksual. Pada tindak lanjut 12 bulan, ada dampak hanya pada subskala kekerasan dan pekerjaan rumah tangga. Penelititan tersebut menemukan perkiraan dampak yang semakin sedikit dan kurang tepat pada domain yang terkait dengan hubungan seksual, dan kesehatan reproduksi mungkin dijelaskan oleh fakta bahwa lebih sedikit remaja yang memiliki pengalaman langsung tentang masalah ini dalam sampel di mana kurang dari satu orang di dalamnya di Lima (17\%) dari 14 hingga 19 tahun melaporkan pernah melakukan hubungan seksual pada awal. Hubungan seksual yang terlalu dini menjadi salah satu kerentanan yang paling dirasa ketika individu merasa nyaman dengan hubungan yang tidak mengikat dan dilalkukan tanpa menggunakan pengaman seperti kondom, akibatnya dari hal tersebut timbul kasus kehamilan tidak di inginkan marak terjadi diperparah dengan aborsi sebagai langkah ekstrim. Seperti pada temuan salah satu artikel The complex relationship between contraception and abortion bahwa "As overall contraceptive use increases, choice of methods becomes a more important influence on the likelihood of unintended pregnancies and abortions. (Cleland, 2020). Ini menandakan, meningkatnya penggunaan kontrasepsi secara keseluruhan, pilihan metode menjadi lebih penting di pengaruh pada kemungkinan kehamilan yang tidak di inginkan dan aborsi. Hal tersebut tentu saja di dukung dengan fasilitas informasi yang memadai pihak terkait.
Wawasan tentang kontrasepsi untuk menghindari dari resiko kehamilan tidak di inginkan mendapat dukungan serupa dari artikel Improving access to and use of contraception by adolescents: What progress has been made, what lessons have been learnt, and what are the implications for action? Yang menjelaskan bahwa "Efforts to build individual competence, and shared norms of sensitivity and enthusiasm, should be combined with approaches to hold service providers accountable to consumers through enhancing the quality of information that consumers have on their rights, creating mechanisms for the participation of communities in oversight mechanisms, and establishing community groups to advocate for their rights. Adolescents are often asked for their opinions (voice). That is important to do but in addition, involving them in such mechanisms would give them the 'teeth' they need to make health service providers and services more accountable." (Chandra-Mouli, Akwara , \& Consultant, 2020). Dimana upaya untuk membangun kompetensi individu, dan norma bersama tentang kepekaan dan antusiasme harus dikolaborasikan dengan pendekatan untuk meminta akuntabilitas penyedia layanan kepada konsumen melalui peningkatan kualitas informasi yang dimiliki konsumen tentang hak-hak mereka, menciptakan mekanisme partisipasi masyarakat dalam mekanisme pengawasan, dan membentuk kelompok masyarakat untuk memperjuangkan hak-hak mereka. Menyendiri dengan resiko bukan sebuah tren atau pilihan yang dapat dipilih, karena setiap manusia satu dengan yang lain saling 
membutuhkan satu dengan yang lain pun dengan ikatan yang jelas serta di sahkan oleh norma atau hokum yang berlaku. Tidak jarang, pria atau wanita yang lelah dengan stigma masyarakat serta kerentanan wanita yang menanggung trauma atas dampak dari kekerasan menjadikan pernikahan sebagai pelindung dari hal tersebut. Pernikahan menjadi salah satu bagian dari tugas perkembangan yang ditandai dengan ketertarikan interpersonal, Baron 259:2016 secara lengkap mengungkapkan bahwa bagaimana ketertarikan interpersonal bagaimana bertemu, menyukai dan menjadi kenal sebagai langkah awal suatu hubungan yang matang. Tidak dapat dipungkiri bahwa kehidupan berkeluarga merupakan suatu gerbang utama dari keberlangsungan kehidupan, sebuah studi Family businesses in the Arab Middle East: What do we know and where should we go? mengungkapkan tentang keluarga di wilayah arab bahwa "The prevalence of Islam as an institution granting the right to polygamous marriages may result in different family dynamics being developed in the Arab Middle East, dynamics not traditionally encountered in Western family businesses. For instance, polygamous marriages may result in new dynamics between siblings sharing the same father but different mothers. Hence, understanding the interaction between marriage types and relationships between family members in the workplace can provide nuanced insights on the sources and potentia solutions to different kinds of conflict that may develop in Arab Middle Eastern family businesses."(Samara, 2020). Prevalensi Islam sebagai institusi yang memberikan hak untuk pernikahan poligami mengakibatkan dinamika keluarga yang berbeda berkembang di Timur Tengah Arab, dinamika yang secara tradisional tidak dihadapi dalam bisnis keluarga Barat. Misalnya, perkawinan poligami dapat menghasilkan dinamika baru antara saudara kandung yang memiliki ayah yang sama tetapi ibu yang berbeda. Oleh karena itu, memahami interaksi antara jenis pernikahan dan hubungan antara anggota keluarga di tempat kerja dapat memberikan wawasan yang berbeda tentang sumber dan solusi potensial untuk berbagai jenis konflik yang mungkin berkembang dalam bisnis keluarga Arab Timur Tengah. Hal demikian membuat pernikahan bukan sebatas hubungan mikro antara calon pasangan laki - laki dengan perempuan namun kepada hubungan yang makro antara calon pasangan pengantin. Keluarga yang besar mencakup dari adanya keturunan dari calon pasangan, Dalam jurnal The impact of teachings on sexuality in Islam on HPV vaccine acceptability in the Middle East and North Africa region menjelaskan bahwa "Mental and physical health are affected by religion, which plays a protective role in hindering the occurrence of diseases. Similarly, the perception and understanding of diseases and the acceptance or refusal of certain treatment techniques or preventive measures is significantly impacted by religion. In the case of HPVpreventive measures, it has been asserted that conservative cultural and religious viewsmayconstitute barriers to their acceptance. For instance, qualitative studies have shown that among parents' principal concerns are discussing sexual activity with their children, and the perception that a consent to vaccinate is a tacit encouragement to 
become sexually active. Studies conducted in Britain have shown that acceptance of the vaccine was less likely among adolescents who are practicing Muslims." (Hamdi, 2018). Kesehatan mental dan fisik dipengaruhi oleh agama, yang berperan sebagai pelindung dalam menghambat terjadinya penyakit. Demikian pula, persepsi dan pemahaman tentang penyakit dan penerimaan atau penolakan teknik pengobatan tertentu atau tindakan pencegahan secara signifikan dipengaruhi oleh agama. Dalam kasus tindakan pencegahan HPV, telah ditegaskan bahwa pandangan budaya dan agama yang konservatif dapat menjadi penghalang bagi penerimaan mereka.

Misalnya, penelitian kualitatif menunjukkan bahwa di antara perhatian utama orang tua adalah mendiskusikan aktivitas seksual dengan anak-anak mereka, dan persepsi bahwa persetujuan untuk vaksinasi adalah dorongan diam-diam untuk menjadi aktif secara seksual. Studi yang dilakukan di Inggris telah menunjukkan bahwa penerimaan vaksin lebih kecil kemungkinannya di kalangan remaja yang muslim. Tentunya memperoleh kesuburan dalam memperoleh keturunan selain hal di atas juga di dukung dengan gaya hidup yang sehat dari laki - laki maupun perempuan, hal tersebut bukan hanya omong kosong tentang kemandulan bukti gaya hidup berpengaruh terhadap kesuburan disampaikan pada artikel Potential causes of male and female infertility in Qatar yang mengungkapkan bahwa "Evidence have shown a significant impact of potentially modifiable lifestyle factors on reproductive performance. Lifestyle factors including psychological stress, smoking, exposure to environmental pollutants, sports, weight and caffeine and alcohol consumption might impact fertility." (Zauner \& Girardi, 2020) sebagai bukti telah menunjukkan tanda fi dampak potensial dari gaya hidup mampu mempengaruhi kinerja reproduksi. Faktor gaya hidup termasuk stres psikologis, merokok, paparan polutan, lingkungan, olahraga, berat badan dan mengkonsumsi kafein serta alkohol. Semakin semaraknya tren yang banyak menjadikan remaja atau dewasa dengan usia siap menikah menjadi rentan dan kehilangan diri untuk lebih mengetahui wawasan berumah tangga, dukungan lingkungan yang memudar membuat individu tersebut menjadi tidak menyadari adanya budaya yang nilainya dekat dengan hal - hal berkaitan dengan pernikahan.

Melalui penelitian ini, bertujuan untuk mengembalikan budaya yang sejatinya sudah ada di lingkungan untuk dapat di aplikasikan bagi mereka yang akan melangsungkan ikatan yang lebih sakral sebagai solusi dari stigmasisasi lajang dan kerentanan kekerasan yang diterima oleh orang - orang dengan risiko kehamilan tidak di inginkan serta membantu untuk pihak terkait mempromosikan untuk memiliki keluarga terencana.

\section{METODE PENELITIAN}

Penelitian penulis kali ini menggunakan pendekatan kuantitatif deskriptif, Sugiyono (2017:8) metode penelitian kuantitatif yakni metode yang berlandaskan pada filsafat positivisme, digunakan untuk meneliti pada populasi dan sampel tertentu, pengumpulan data menggunakan instrument penelitian, analisis data bersifat statistik.

Populasi dan Sampel Penelitian 
Populasi menurut Sugiyono (2017:80-81) adalah wilayah generalisasi yang terdiri atas: obyek/subyek yang mempunyai kualitas dan karakteristik tertentu yang ditetapkan oleh peneliti untuk dipelajari dan kemudian ditarik kesimpulannya sedangkan Sampel yaitu bagian dari jumlah dan karakteristik yang dimiliki oleh populasi tersebut. Nurul (2009:116-119) populasi adalah seluruh data yang menjadi perhatian peneliti dalam suatu ruang lingkup dan waktu yang ditentukan sedangkan sampel sering diartikan sebagai bagian dari populasi. Mahmud, 2011:155 menambahkan populasi dan sampel menunjukan generalisasi konklusi penelitiannya. Proses penelitian ini dilakukan antara bulan Agustus. Populasi terdiri dari laki-laki dan perempuan yang akan menikah. Sampel sebanyak 50 responden dari laki-laki dan perempuan menjelang pernikahan di wilayah Jawa.

Variabel Penelitian

Menurut Sugiyono (2017:39) "Suatu atribut, sifat atau nilai dari obyek atau kegiatan yang mempunyai variasi tertentu yang ditetapkan oleh peneliti untuk dipelajari dan kemudian ditarik kesimpulannya." Adapun yang menjadi indikator dari suatu variable dalam penelitian ini yaitu kondisi hubungan, cinta remaja, persiapan pernikahan, pager ayu, ladhen wedhang serta rewang.

Teknik Pengumpulan Data

Teknik dalam mengumpulkan data dilakukan dengan kuesioner yang diisi oleh 50 responden yang merupakan calon pasangan pengantin yang ada di wilayah Jawa menggunakan aplikasi google form, wawancara dan dokumentasi foto.

Analisis Data
Analisis data dengan menggunakan aplikasi SPPS. Proses analisis data menggunakan statistik inferensial untuk mengetahui validitas dan reliabilitas instrumen. Analisis statistik deskriptif untuk mengetahui mean, median dan modus.

utama, tempat, teknik pengumpulan data, definisi operasional variable penelitian, dan teknik analisis. (times new roman 11 normal)

\section{HASIL DAN PEMBAHASAN}

Pengumpulan data telah dilakukan oleh peneliti dengan menyebar instrument melalui media google form yang tersebar di seluruh wilayah Indonesia dari bulan Juli hingga Agustus 2020 dengan responden terkumpul sebanyak 50 responden, Data yang telah terkumpul kemudian masuk tahap uji. Uji validitas dan reliabilitas merupakan langkah selanjutnya dalam pelaksanaan penelitian setelah membagikan assessment berupa angket. Seberapa tinggi kepercayaan dapat diberikan kepada penelitian sangat bergantung pada akurasi dan kecermatan data yang diperoleh, data yang tidak valid dan tidak reliable akan memberikan informasi yang tidak akurat mengenai validitas dan reliabilitas yang dianalisis, (S., 2018)

Validitas merupakan deskirpsi yang benar mengenai variable yang diukur, validitas dapat ditentukan dengan menggunakan $r$ table produk dengan taraf signifikan yang dipakai adalah sebsar $5 \%$ jika nilai $r$ hitung $>r$ table $=$ valid, begitupun sebaliknya. Pada kali ini hasil validitas dengan reponden sebanyak 50 maka $r$ table yang diperoleh adalah 0,279. Dengan dihitung menggunakan aplikasi SPSS menunjukan hasil sebagai berikut : 


\begin{tabular}{|c|c|c|c|}
\hline Indikator & $\begin{array}{c}\text { No. Butir } \\
\text { Instrume } \\
n\end{array}$ & $\begin{array}{c}\text { Koefisie } \\
n \\
\text { korelasi }\end{array}$ & $\begin{array}{c}\text { Keteranga } \\
\mathrm{n}\end{array}$ \\
\hline \multirow{10}{*}{$\begin{array}{l}\text { Kondisi } \\
\text { Hubungan }\end{array}$} & 1 & .423 & \multirow{2}{*}{ Valid } \\
\hline & 2 & .344 & \\
\hline & 3 & .172 & $\begin{array}{l}\text { Tidak } \\
\text { Valid }\end{array}$ \\
\hline & 4 & .569 & \multirow[t]{39}{*}{ Valid } \\
\hline & 5 & .621 & \\
\hline & 6 & .508 & \\
\hline & 7 & .353 & \\
\hline & 8 & .435 & \\
\hline & 9 & .396 & \\
\hline & 10 & .380 & \\
\hline \multirow{9}{*}{$\begin{array}{l}\text { Cinta } \\
\text { Remaja }\end{array}$} & 11 & .711 & \\
\hline & 12 & .800 & \\
\hline & 13 & .775 & \\
\hline & 14 & .647 & \\
\hline & 15 & .699 & \\
\hline & 16 & .595 & \\
\hline & 17 & .536 & \\
\hline & 18 & .337 & \\
\hline & 19 & .431 & \\
\hline \multirow{6}{*}{$\begin{array}{l}\text { Persiapan } \\
\text { Pernikaha } \\
\mathrm{n}\end{array}$} & 20 & .547 & \\
\hline & 21 & .479 & \\
\hline & 22 & .641 & \\
\hline & 23 & .585 & \\
\hline & 24 & .311 & \\
\hline & 25 & .375 & \\
\hline \multirow[t]{7}{*}{ Pager Ayu } & 26 & .794 & \\
\hline & 27 & .818 & \\
\hline & 28 & .792 & \\
\hline & 29 & .566 & \\
\hline & 30 & .588 & \\
\hline & 31 & .417 & \\
\hline & 32 & .465 & \\
\hline \multirow{5}{*}{$\begin{array}{l}\text { Ladhen } \\
\text { Wedhang }\end{array}$} & 33 & .606 & \\
\hline & 34 & .557 & \\
\hline & 35 & .754 & \\
\hline & 36 & .723 & \\
\hline & 37 & .291 & \\
\hline \multirow[t]{5}{*}{ Rewang } & 38 & .498 & \\
\hline & 39 & .726 & \\
\hline & 40 & .749 & \\
\hline & 41 & .365 & \\
\hline & 42 & .512 & \\
\hline
\end{tabular}

Tabel 1. Hasil validitas instrumen

Berdasarkan hasil tersebut, dengan demikian variabel dalam budaya sinoman Jawa memiliki tingkat kevalidan yang kuat sebanyak 41 item dan satu item tidak valid pada nomor tiga dengan bunyi item berikut "Kami dikenalkan oleh rekan kerja" artinya tidak semua calon pasangan dari 50 responden berasal dari lingkungan tempat dirinya bekerja karena hal tersebut berkaitan dengan fokus dari tuntutan tempat individu tersebut bekerja.

Uji reliabilitas digunakan untuk menentukan tingkat kepercayaan dari suatu instrument. Dari Azwar mengatakan bahwa suatu data dikatakan reliabel jika mempunyai nilai koefisien $>0.80$ menggunakan Cronbach alpha. (S., 2018)

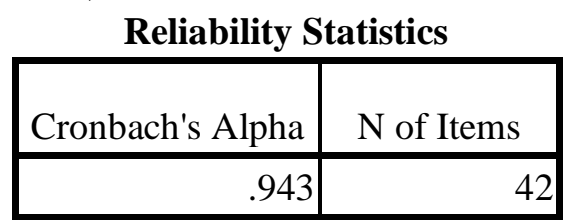

Tabel 2. Hasil uji reliabilitas instrument

Hasil uji reliabilitas menunjukan koefisien reliabilitas sebesar $\alpha=0.943$. Dengan demikian instrumen konseling pernikahan berbasis budaya Sinoman jawa reliable atau dapat dipercaya.

Pada kali ini hasil mean dengan reponden sebanyak 50 maka hasil mean yang diperoleh adalah 110.38, dengan nilai median 107.50 , dan nilai mode 88. Dengan dihitung menggunakan aplikasi SPSS menunjukan hasil berikut :

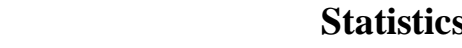

TOTAL

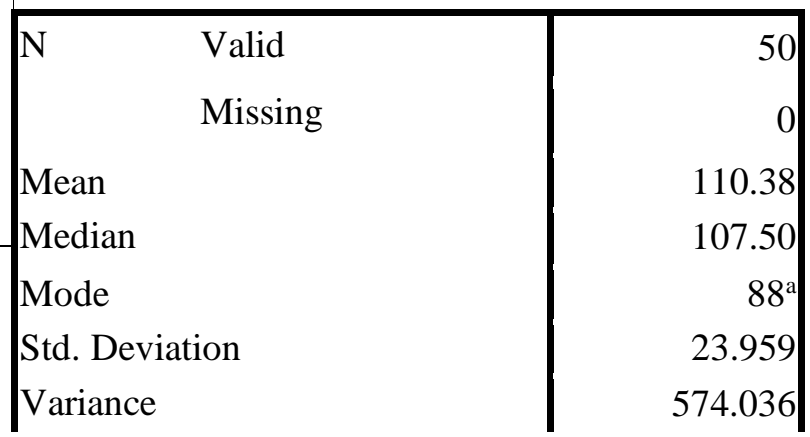


\begin{tabular}{|l|r|} 
Range & 123 \\
Minimum & 45 \\
Maximum & 168 \\
\hline
\end{tabular}

a. Multiple modes exist. The smallest value is shown

Tabel 3. Hasil Uji Mean, Median dan Mode

Data yang terkumpul menggunakan google form yang terdiri dari 50 responden dengan dominasi jenis kelamin perempuan, Usia dari responden yang tersebar adalah berkisaran dari rentang 16 hingga 29 Tahun memasuki usia persiapan pernikahan dan sedang menjalani masa kenal dekat dengan lawan jenis atau pacaran. Responden berasal dari domisili beberapa wilayah di pulau Jawa dengan perolehan tiga tertinggi dari Pemalang sebesar $17.1 \%$, Kabupaten Tegal sebesar 22,9\% dan Kabupaten Brebes sebesar 24,3\% serta total kesiapan pernikahan masih lama dari 50 responden memberikan hasil $55,7 \%$ hal tersebut dapat dijadikan acuan untuk memberikan wawasan tentang pentingnya informasi menjelang pernikahan yang perlu dipersiapkan. Ada beberapa hal yang perlu dipersiapkan dalam sebuah proses menjelang pernikahan. Hal tersebut dimaksudkan agar calon pasangan pengantin baik laki - laki maupun perempuan memiliki pandangan terhadap bagaimana rumah tangga yang mereka bina. Upaya - upaya dari pemberian bantuan untuk membantu calon pengantin mempersiapkan pengetahuan tentang rambu - rambu pernikahan disebut dengan konseling pernikahan. Konseling pernikahan memberikan beberapa pendekatan pendekatan salah satunya memasukan pendekatan dengan berbasis budaya sekitar lingkan tempat calon pengantin tinggali. Budaya dalam bahasa sansekerta yaitu buddhayah merupakan bentuk jamak dari buddhi (budia atau akal) yang diartikan sebagai hal - hal berkaitan dengan budi dan akal manusia. Bagi tiap - tiap daerah di Jawa Tengah, khususnya wilayah pantura terdapat budaya yang khusus untuk membantu dalam pelaksanaan kegiatan pesta pernikahan. Budaya tersebut tidak lepas dari mulai pemilihan hari baik dalam melaksanakan pernikahan hingga saat pelaksanaan pernikahan yang prinsipnya dapat digunakan sebagai pendekatan konseling pernikahan berbasis kultural atau budaya. Di wilayah Jawa bagian Kabupaten Tegal, menetapkan acaranya pada bulan bulan yang baik berdasarkan kalender Jawa atau kalender Hijriah maupun dengan menyesuaikan hari libur dari kedua pihak calon pasangan pengantin. Pada bagian wilayah tertentu Kabupaten Tegal jika telah menetapkan tanggal pernikahan kemudian terdapat kesamaan tanggal dengan tetangga nantinya kedua belah pihak berdiskusi atau salah satu keluarga ada yang mengalah. Sebelum menjalani pernikahan, ada hari dimana kedua calon pengantin harus menjalani tradisi berada dirumah saja selama satu minggu dan menjalani puasa mutih. Puasa mutih merupakan puasa dengan menahan nafsu makan dan minum seperti puasa pada umumnya, letak perbedaan pada menu sahur dan berbuka yang hanya nasi dan air putih. Hal tersebut yang membuat puasa ini disebut mutih dalam bahasa jawa berarti putih. Dengan tujuan agar ketika di rias, kedua calon pengantin memiliki aura yang berbeda.

Masih sekitar wilayah Jawa yakni di Pemalang dalam adat untuk 
mempersiapkan pernikahan masih mempertahankan tradisi Jawanya, sebelum pernikahan calon pengantin akan di hitung wetonnya terlebih dahulu, namun perhitungan weton di desa tidak hanya untuk pernikahan saja, namun diberbagai aspek lainnya seperti, hajatan, walimahan, lamaran, jual beli, pembangunan dan lain sebagainya.

Masyarakat di Pemalang (khususnya di desa pelosok) masih sangat melestarikan budaya weton ini, menurut mereka pernikahan itu merupakan acara yang sangat sakral dan harus benarbenar memperhitungkan weton untuk kedua calon pengantin. Mereka percaya dengan menghitung weton mereka akan mengetahui baik atau tidaknya calon pasangan pengantin, maka dari pihak laki-laki akan menghitung neptu kedua calon pengantin dan di jumlahkan keduanya lalu dihitung hingga lima maka akan kembali pada satu, demikian hingga jumlah penggabungan bilangan neptu kedua calon pengantin, Penggunaan perhitungan weton dalam pernikahan merupakan hal yang wajib bagi sebagian masyarakat Pemalang.

Sistem perkawinan yang di anut oleh masyarakat Pemalang sendiri menganut sistem bebas, yang artinya, memperbolehkan orang menikah antar daerah. Sedangkan, tempat tinggal yang dianut setelah perkawinan adalah matrilokal. Pada masa lalu, seorang pengantin laki - laki mulai bekerja setelah usia pernikahan mereka tujuh hari setelah akad nikah. Selama tujuh hari ini pengantin hanya bersih - bersih halaman rumah, saat ini kebiasaan tersebut jarang dilakukan karena luasnya halaman yang makin jarang dimiliki masyarakat.

Suatu proses pemberian bantuan dari konselor terhadap individu yang membutuhkan atau konseli disebut dengan konseling. Secara detail konseling disampaikan oleh Prayitno dan Erman Amti, 105:2004 sebagai proses pemberian bantuan yang dilakukan melalui wawancara konseling seorang ahli (disebut konselor) kepada individu yang sedang mengalami suatu masalah (disebut konseli atau klien) yang bermuara pada teratasinya masalah yang dihadapi konseli atau klien. Layanan konseling ini bukan hanya ketika individu memiliki masalah, namun juga sebagai pencegahan dari kasus - kasus yang dikhawatirkan muncul pada masa mendatang disebut dengan layanan preventif.

Pemberian bantuan layanan preventif bagi calon pengantin ini tidak memandang latar belakang baik ekonomi hingga pendidikan berhak untuk mendapatkan layanan. Dari Jurnal Challenges faced by married university undergraduate female students in Ogun State, Nigeria mengungkapkan bahwa "The findings of the study suggest the need for counselling intervention to reduce the effect of the challenges faced by this category of students. Hence the following interventions are proposed to ameliorate the stress of combining family life and study." (Lasode \& Awotedu, 2014).

Artinya bahwa tantangan yang dihadapi oleh pasangan yang memiliki keterikatan dunia pendidikan lebih tinggi dalam menjalani kehidupan keluarga berdampingan dengan tanggung jawabnya sebagai seseorang yang menjalani Pendidikan.

Hal tersebut mengakibatkan stress yang mengkhawatirkan apabila tidak dicegah dengan tepat menggunakan konseling pernikahan. 
Pendekatan yang dapat diberikan selama konseling pernikahan ragamnya bervariasi seiring dengan perkembangan zaman, eksistensi dari budaya yang ada turut andil memberikan kontribusinya untuk memberitahukan kepada generasi agar tidak lupa pada jati dirinya. Termasuk pendekatan konseling pernikahan yang penulis gunakan dengan berbasis pada budaya Sinoman Jawa yang memiliki nilai pada prinsip untuk dijadikan layanan preventif pada konseling pernikahan. Sinoman merupakan budaya gotong royong yang dilakukan masyarakat Jawa. Sinoman sering dijumpai menjelang pernikahan di rumah kedua mempelai. Dahulu, remaja muda yang menginjak umur pernikahan menjadi yang dominan dalam melakukan kegiatan Sinoman adalah remaja muda yang usianya menginjak pada pernikahan. Beberapa orang yang Sinoman dibagi tugasnya berdasarkan permintaan dari yang punya hajat atau orang yang melangsungkan acara pernikahan baik dari orang tua maupun langsung dari calon pasangan pengantin.

Pembagian tugas tersebut harus di jalankan sesuai dengan pembagiannya dan tidak diperbolehkan mencampuri tugas satu dengan yang lain karena di khawatirkan akan mengganggu. Hal tersebut sesuai dengan urusan rumah tangga yang pembagian tugasnya dalam rumah tangga tidak diperbolehkan dicampuri siapapun entah itu dari luar rumah tangga tersebut atau dari dalam misalkan orang tua dari pasangan. Pembagian tugas tersebut bersifat fleksibel, ketika seseorang merasa kerepotan maka yang lain membantu.

Hal ini sesuai dengan pemikiran bahwa berumah tangga kita harus diupayakan berdua bersama pasangan, ketika sudah mencapai titik tertentu yang tidak dapat ditangani bersama pasangan barulah meminta saran dari kedua orang tua, diusahan untuk tidak terbiasa terlalu sering melibatkan orang tua untuk urusan rumah tangga sebagai langkah meminimalisir terjadinya memperkeruh kondisi.

Kegiatan meminta tolong untuk membantu pernikahan tersebut merupakan warisan dari leluhur, dituturkan oleh sesepuh desa bahwa kegiatan Sinoman ini sudah ada sejak nenek moyang singgah di Jawa. Budaya Sinoman memiliki nilai atau arti mendalam, Nilai tersebut sarat akan makna dan dapat dijadikan prinsip pada pendekatan konseling pernikahan. Pembagian Sinoman beserta maknanya terangkum menjadi beberapa bagian depan sebagai penyambut tamu dan bagian dapur.

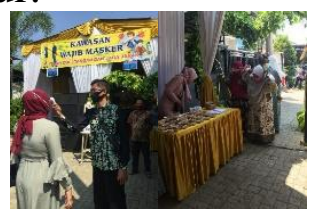

Gambar 1. Kegiatan Pager Ayu

Bagian menangani tamu, disebut dengan Pager Ayu, Pager Ayu merupakan orang yang berdiri untuk menyambut dan menerima tamu dengan jumlah lebih dari satu bertugas sebagai pencatat tamu undangan. Orang yang menjadi Pager Ayu diperankan oleh wanita dan di rias, Arti dari proses ini adalah seseorang yang menjalani rumah tangga harus memegang teguh nilai menerima bagaimanapun latar belakang dari pasangan serta selalu memberikan pelayanan terbaik bagi pasangan meskipun saat itu situasi, kondisi dan suasana perasaan kurang mendukung. Di era pandemi COVID-19, pager ayu tidak lagi hanya di dominasi oleh perempuan namun juga menambah laki - laki untuk membantu dalam 
pelaksanaan kegiatan pernikahan sebagai upaya dari penerapan protokol kesehatan. Ini artinya, ada hubungan bahwa laki - laki dan perempuan memang harus saling bahu membahu.

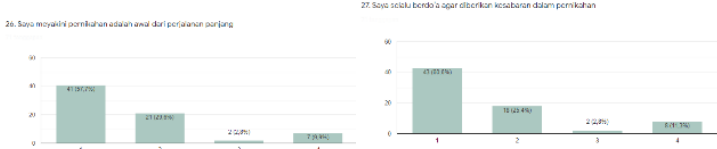

Gambar 2. Grafik Item Pager Ayu

Hasil dari grafik dengan item nomor 26 dan 27 memiliki tingkat validitas yang tertinggi dari indikator ini, pada item nomor 26 memiliki perolehan sebanyak $57,7 \%$ dan pada item nomor 27 sebanyak 60,6\% Sangat Setuju terhadap item hal tersebut sesuai dengan prinsip pada pager ayu dimana pager ayu ini merupakan gerbang awal dari tempat berlangsungnya kegiatan pernikahan sama seperti keyakinan bahwa orang yang memutuskan untuk menikah sama dengan meyakini dirinya telah masuk pada gerbang perjalanan panjang dalam rumah tangganya dan item nomor 27 melengkapi dengan pernyataan tentang kesabaran dalam antri untuk masuk kedalam selaras dalam memberikan pelayanan selama mengaruhi rumah tangga.

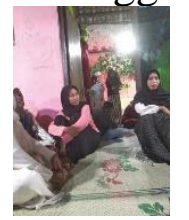

Gambar 3. Kegiatan Ladhen Wedhang

Selanjutnya untuk bagian tamu, ada ladhen wedhang. Ladhen wedhang ialah individu yang bertugas untuk memberikan minuman atau jamuan kepada para tamu, Biasanya dilakukan oleh wanita untuk tamu wanita serta laki - laki untuk tamu laki - laki. Artinya adalah dalam berumah tangga, pasangan harus memperhatikan keramahan dalam menuangkan rasa kasih sayang kepada orang tua pasangan juga dalam membina rumah tangga supaya hubungan rumah tangga yang dijalani selalu adem atau tidak panas.

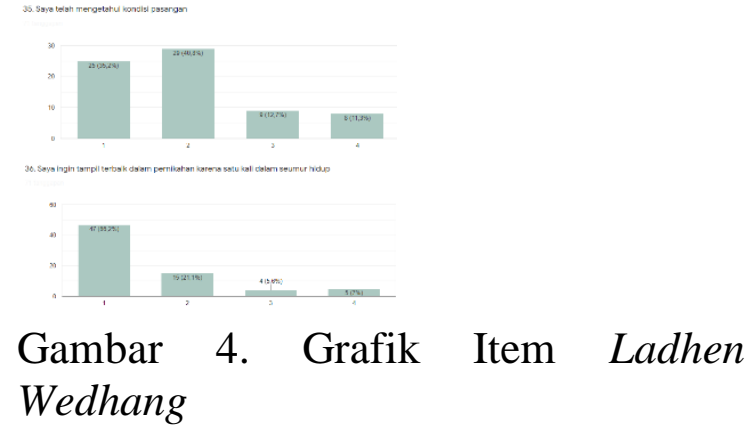

Hasil dari grafik dengan item nomor 35 dan 36 mendapatkan perolehan tertinggi untuk indikator ladhen weedhang sebanyak $30,8 \%$ setuju dan $66,2 \%$ sangat setuju kepada pernyataan item hal tersebut sesuai dengan memberikan tampilan pribadi terbaik dari seseorang sebagai individu yang telah memutuskan menjadi bagian dari keluarga sang pasangan apapun kondisi dari keluarga pasangannya.

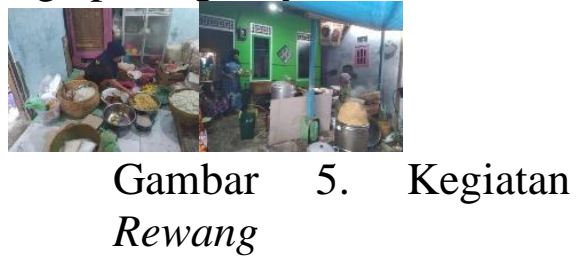

Lalu bagian dapur, Bagian dapur dalam Sinoman ini menjadi inti karena seluruh kegiatan dalam Sinoman berpusat di dapur. Mulai dari kegiatan memasak nasi, lauk hingga memasak air untuk para tamu. Orang yang mendapat tugas Sinoman di dapur biasanya akan berkutat dengan bumbu dapur, sayur dan asap. Makna dari bagian di dapur ini adalah calon pengantin memahami tujuan dari sebuah rumah tangga, tujuan tersebut hasil nyata dari pemahaman tentang urusan berumah tangga yang tidak hanya tentang kesenangan kasur, namun juga bagaimana dapat mengupayakan dapur selalu mengepulkan asap (Ngebhul). 


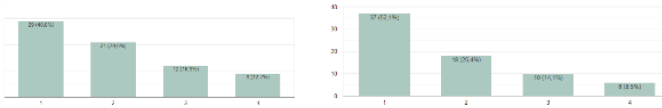

Gambar 6. Grafik Item Rewang

Hasil dari grafik dengan item 49 dan 40 memberikan hasil tingkat valid tertinggi pada indikator rewang dengan perolehan sangat setuju sebanyak $40,8 \%$ dan $52,1 \%$ hal tersebut selaras dengan arti prinsip rewang dimana tujuan dari berumah tangga adalah membangun hubungan tidak sebatas pada kesenangan seksual akan tetapi membangun hubungan batin baik antara dirinya dengan pasangan maupun dengan keluarga. Melibatkan pasangan untuk selalu bertukar fikiran sebelum memutuskan sesuatu menjadikan pasangan merasa lebih diakui keberadaannya serta rasa hormat dan menyayangi orang tua dari pasangan memunculkan dukungan lebih yang dirasakan oleh pasangan.

Sinoman pada pihak wanita lebih banyak dibanding pada pihak pria. Wanita yang mengikuti Sinoman tersebut melakukan banyak tugas hampir seluruhnya tugas lebih banyak pada wanita, jika dilihat dari kegiatan tersebut maka prinsip Sinoman yang bisa dipergunakan dalam konseling pernikahan lebih dari sekedar menjadi seorang pendamping namun juga menjadi seorang manajer keuangan. Ketika wanita sudah memutuskan menikah, dirinya harus menanggalkan seluruh egonya untuk menaruh perhatian kepada rumah tangga supaya langgeng hal tersebut selaras dengan peran wanita pada Prinsip Sinoman yang dimana acara pesta pernikahan dapat tercapai tujuannya bila bagian tugas wanita dikerjakan dengan penuh perhatian. Pendekatan Prinsip Sinoman ini dapat digunakan kepada konseli yang melakukan konseling pernikahan dengan gejala tingkah laku masih kebingungan tentang kehidupann berkeluarga.

Terutama pada wanita, prinsip Sinoman ini perlu ditekankan karena ketika menjalani bahtera pernikahan wanita lah yang akan memiliki peran lebih banyak dan dekat dengan orang tua baik itu dari pasangan atau mertua maupun orang tuanya. Selain kepada calon pasangan yang menunjukan kebingungan menjalani bahtera rumah tangga, prinsip ini juga dapat diterapkan pada pasangan yang menggebu - gebu untuk menikah hanya karena hasrat "menikmati malam pertama atau seksualitas ketika berumah tangga" namun ketika ditanyakan seputar tanggung jawab dan hak, pasangan tersebut mengalami ketidak tahuan. Langkah dalam menerapkan prinsip Sinoman pada konseling pernikahan yakni melakukan assessment, kemudian setelah memperoleh hasil dari assessment tersebut kemudian melakukan proses konseling peer group guna memperdalam pemahaman tentang wawasan pernikahan.

\section{KESIMPULAN}

Budaya yang sejatinya sudah ada di lingkungan untuk dapat di aplikasikan bagi mereka yang melangsungkan ikatan yang lebih sakral sebagai solusi dari stigmasisasi lajang dan kerentanan terhadap kekerasan yang diterima oleh orang - orang dengan risiko kehamilan tidak di inginkan serta membantu untuk pihak terkait mempromosikan untuk memiliki keluarga terencana. Metode yang digunakan dalam penelitian ini adalah kuantitatif deskriptif dimana data dikumpulkan menggunakan google form terdiri dari 50 responden dengan dominasi jenis kelamin perempuan, 
Usia dari responden yang tersebar adalah berkisaran dari rentang 16 hingga 29 Tahun memasuki usia persiapan pernikahan dan sedang menjalani masa kenal dekat dengan lawan jenis atau pacaran.

Responden berasal dari domisili beberapa wilayah di pulau Jawa dengan perolehan tiga tertinggi dari Pemalang sebesar 17.1\%, Kabupaten Tegal sebesar 22,9\% dan Kabupaten Brebes sebesar 24,3\% serta total kesiapan pernikahan masih lama dari 50 responden memberikan hasil $55,7 \%$ hal tersebut dapat dijadikan acuan untuk memberikan wawasan tentang pentingnya informasi menjelang pernikahan yang perlu dipersiapkan. Tingkat kevalidan data yang dikumpulkan merujuk pada indikator variable kondisi hubungan, cinta remaja, persiapan pernikahan, pager ayu, ladhen wedhang serta rewang pada 50 responden dari beberapa daerah khususnya wilayah Jawa, usia 21 tahun keinginan menikah tertinggi memiliki tingkat kevalidan yang kuat sebanyak 41 item dan satu item tidak valid pada nomor tiga dengan bunyi item berikut "Kami dikenalkan oleh rekan kerja" serta reliabilitas menunjukan koefisien reliabilitas sebesar $\alpha=0.943$.

Item tertinggi dengan kesesuaian indikator utama dari Sinoman Jawa yakni pada pernyataan pernikahan sebagai gerbang utama dari perjalanan yang panjang sehingga harus dibarengi dengan limpahan kesabaran untuk mampu menerima apapun kondisi pasangan yang memperoleh layanan terbaik juga terhadap orang tua hal tersebut didukung dengan komunikasi atau tukar pendapat bersama pasangan sebagai kunci terhindari dari permasalahan.

\section{REFERENSI}

Anwar, S. (2014). Pemahaman Individu (Observasi, Checklist, Interviu, Kuesioner, Sosiometri). Yogyakarta: Pustaka Pelajar.

Baron, d. (2016). Psikologi Sosial (Edisi 10). Jakarta: Erlangga.

Chandra-Mouli, V., Akwara , E., \& Consultant, I. (2020). Improving access to and use of contraception by adolescents: What progress has been made, what lessons have been learnt, and what are the implications for action? Best Practice \& Research Clinical Obstetrics and Gynaecology, 66, 107-118. doi:https://doi.org/10.1016/j.bpobgy n.2020.04.003

Choi, S.-H., Yang, E. C., \& Tabari, S. (2020). Solo dining in Chinese restaurants: A mixed-method study in Macao. International Journal of Hospitality Management, V.90, 1-10. doi:https://doi.org/10.1016/j.ijhm.20 20.102628

Chzhen, Y., Prencipe, L., Eetaama, F., Luchemba, P., Lukongo, T. M., Palermo, T., \& Team, o. b. (2020). Impact of a Cash Plus Intervention on Gender Attitudes Among Tanzanian Adolescents. Journal of Adolescent Health, Journal of Adolescent Health xxx (2020) 1e7, 17.

doi:https://doi.org/10.1016/j.jadoheal th.2020.07.025

Cleland, J. (2020). The complex relationship between contraception and abortion. Best Practice \& Research Clinical Obstetrics and Gynaecology, V.62, 90-100. doi:https://doi.org/10.1016/j.bpobgy n.2019.04.007

Feng, Z., Cramm, J. M., Jin, C., Twisk, J., \& Nieboer, A. P. (2020). The longitudinal relationship between 
income and social participation among Chinese older people. SSM Population Health, V.11, 1-8. doi:https://doi.org/10.1016/j.ssmph.2 020.100636

Gressel, C. M., Rashed, T., Maciuika, L. A., Sheshadri, S., Coley, C., Kongeseri, S., \& Bhavani, R. R. (2020). Vulnerability mapping: A conceptual framework towards a context-based approach to women's empowerment. World Development Perspectives, $\quad$ V.20, 1-12. doi:https://doi.org/10.1016/j.wdp.202 0.100245

Hamdi, S. (2018). The impact of teachings on sexuality in Islam on HPV vaccine acceptability in the Middle East and North Africa region. Journal of Epidemiology and Global Health, V. 7, S17-S22. doi:https://doi.org/10.1016/j.jegh.201 8.02.003

Himawan, K. K., Bambling, M., \& Edirippulige, S. (2017). Modernization and singlehood in Indonesia: Psychological and social impacts. Kasetsart Journal of Social Sciences, $\quad V . \quad x x x, \quad 1-8$. doi:https://doi.org/10.1016/j.kjss.201 7.09.008

Lasode, A. O., \& Awotedu, F. (2014). Challenge Faced By Married University undergraduate Female
Students In Ogun State, Nigeria. Elsevier, 112, 102 - 113. doi:doi: 10.1016/j.sbspro.2014.01.1144

Mahmud. (2011). Metode Penelitian Pendidikan. Bandung: Pustaka Setia.

Nurul, Z. (2009). Metodologi Penelitian Sosial dan Pendidikan (Teori Aplikasi). Jakarta: Bumi Aksara.

Prayitno, \& Amti, E. (2004). Dasar dasar Bimbingan dan Konseling. Jakarta: Rieka Cipta.

S., A. (2018). Metode Penelitian Psikologi (Edisi II). Yogyakarta: Pustaka Pelajar.

Samara, G. (2020). Family businesses in the Arab Middle East: What do we know and where should we go? Journal of Family Business Strategy, Journal of Family Business Strategy $x x x \quad(x x x x) \quad x x x x, \quad 1-16$. doi:https://doi.org/10.1016/j.jfbs.202 0.100359

Sugiyono. (2017). Metode Penelitian Kuantitatif, Kualitatif dan $R \& D$. Bandung : Alfabeta.

Willis, S. S. (2017). Konseling Keluarga. Bandung: Alfabeta.

Zauner, G., \& Girardi, G. (2020). Potential causes of male and female infertility in Qatar. Journal of Reproductive Immunology, V. 141, 113. doi:https://doi.org/10.1016/j.jri.2020. 103173 